\title{
Mempertahankan Tradisi Berkarakter dalam Inovasi
}

\section{Mohamad Mahrusillah}

SPs UIN Syarif Hidayatullah Jakarta, Indonesia

mmahrusillah@gmail.com

\section{Abstrak:}

Tulisan ini berusaha membahas mengenai bagaimana manajemen Pesantren Maslakul Huda Kajen Pati Jawa Tengah dalam pembentukan Insan Mandiri. Dalam penelitian yang penulis lakukan melalui metode penelitian lapangan dapat dikatakan bahwa secara pengelolaan, pesantren Maslakul Huda sudah menggunakan manajemen yang baik dan terukur dimulai dari: sistem rekrutmen pengurus pesantren yang notabenenya santri aktif, sistem pengorganisasian, pengawasan, materi dan metode pendidikan yang bermuara pada terbentuknya insan mandiri.

Kata Kunci: Pesantren, Manajemen, Inovasi.

\begin{abstract}
:
This paper seeks to discuss about the management of the Maslakul Huda Kajen Pati Central Java Pesantren in the formation of Mandiri Individuals. In the research conducted by the writer through the field research method it can be said that in terms of management, the Maslakul Huda pesantren has used good and measurable management starting from: the pesantren board management recruitment system which in fact is active santri, the organizing system, supervision, material and educational methods that lead to the formation of the pesantren management. independent human being.
\end{abstract}

Keywords: Pesantren, Management, Inovation.

\section{Pendahuluan}

Dikatakan oleh Martin van Bruinessen, bahwa salah satu tradisi agung di Indonesia adalah tradisi pengajaran agama Islam seperti yang muncul di pesantren Jawa dan lembagalembaga serupa di luar Jawa serta semenanjung Malaya. Alasan pokok munculnya pesantren ini adalah untuk mentransmisikan Islam tradisional sebagaimana yang terdapat dalam kitabkitab klasik yang ditulis berabad-abad yang lalu. Kitab-kitab ini di Indonesia dikenal sebagai 
kitab kuning. Sebagai lembaga pendidikan yang berbasis agama, pesantren pada mulanya merupakan pusat penggemblengan nilai-nilai dan penyebaran agama Islam. Namun, dalam perkembangannya lembaga ini semakin memperlebar wilayah garapannya yang tidak selalu mengakselerasikan mobilitas vertikal, tetapi juga mobilitas horizontal. Pesantren kini tidak lagi berkutat pada kurikulum yang berbasis keagamaan saja, tetapi juga kurikulum yang menyentuh persoalan kekinian dalam masyarakat. Dengan demikian, pesantren tidak lagi didakwa sematamata sebagai lembaga keagamaan murni, tetapi juga menjadi lembaga sosial yang hidup dan terus merespon persoalan masyarakat sekitar. Di sisi yang lain, blantika perkembangan pesantren belakangan ini ditandai dengan munculnya generasi baru pesantren. Generasi baru ini tetap mewarisi tradisi keilmuan pesantren sebelumnya, juga berhasil meng-creat tradisi yang sama sekali baru sekaligus berhasil mensinergikannya dengan perkembangan keilmuan mutakhir. $^{1}$

Di era global, pesantren tradisional masih tetap relevan untuk tetap dipertahankan dan pesantren harus tetap berupaya menjaga eksistensinya dan menyesuaikan diri dengan kondisi yang melingkupinya tanpa meninggalkan ciri khas kepesantrenan yang dimilikinya. Adaptasi di sini mencakup semua segi dan aspek kepesantrenan tanpa harus meninggalkan ciri-ciri khas kepesantrenan. Dengan adanya upaya tersebut, diharapkan pesantren tidak akan ketinggalan zaman dan selalu relevan dengan kebutuhan zaman. ${ }^{2}$ Menurut Zamachsyari Dhofier, pesantren tradisional adalah lembaga pesantren yang mempertahankan pengajaran kitab-kitab Islam klasik sebagai inti pendidikan. Pesantren adalah lembaga pendidikan tradisional Islam untuk memahami, menghayati dan mengamalkan ajaran agama Islam (tafaqquh fiddin) dengan menekankan moral agama Islam sebagai pedoman hidup bermasyarakat sehari hari.Pesantren berarti tempat para santri. ${ }^{3}$ Keunikan dunia pesantren bisa ditemukan dari tiga unsur penting yang tidak bisa dipisahkan, yaitu santri sebagai anak didik, Kiai sebagai pendidik dan kitab kuning sebagai kurikulum. Ketiga komponen ini menjadi karakteristik dan kekhasan tersendiri dari lembaga pendidikan yang lain. Istilah santri sebagai anak didik tentu berbeda dengan siswa dilembaga formal. Seseorang disebut santri apabila belajar kepada Kiai secara personal maupun kelembagaan, baik santri tersebut masih menimba ilmu di pesantren maupun telah lulus atau keluar dari pesantren. ${ }^{4}$

${ }^{1}$ Mastuki HS, Intelektualisme Pesantren: Seri 3, (Jakarta: Diva Pustaka, 2003), hal. 1

${ }^{2}$ Nia Indah Purnamasari, Konstruksi Sistem Pendidikan Pesantren Tradisional di Era Global: Paradoks dan Relevansi. Sekolah Tinggi Agama Islam YPBWI Surabaya, EL-BANAT: Jurnal Pemikiran dan Pendidikan Islam Volume 6, Nomor 2, Juli-Desember 2016, hal. 211

${ }^{3}$ Zamakhsyari Dhofier, Tradisi Pesantren: Studi Tentang Pandangan Hidup Kiai, (Jakarta: LP3ES, 1982), hal. 18.

${ }^{4}$ Ali Usman, Kiai Mengaji Santri Acungkan Jari, (Yogyakarta: Pustaka Pesantren, 2013), Cet. I, hal. 6 
Nilai pesantren sesungguhnya terletak pada kemanunggalannya dengan masyarakat. Karena itu, keberhasilah suatu pesantren tidak dapat diukur berdasarkan prestasi-prestasi individual santrinya, tetapi sejauh mana santri mampu berinteraksi secara positif dengan masyarakatnya. Secara praktis, ini berarti bahwa eksistensi santri akan sangat ditentukan oleh kemampuannya untuk mengenali dan malayani masyarakat yang nota-bene merupakan perwujudan langsung sebuah pluralitas. Maka tantangan besar bagi setiap santri adalah bagaimana memahami dan memaknai pluralitas. ${ }^{5}$

Keunikan dunia pesantren bisa ditemukan dari tiga unsur penting yang tidak bisa dipisahkan, yaitu santri sebagai anak didik, Kiai sebagai pendidik dan kitab kuning sebagai kurikulum. Ketiga komponen ini menjadi karakteristik dan kekhasan tersendiri dari lembaga pendidikan yang lain. Istilah santri sebagai anak didik tentu berbeda dengan siswa dilembaga formal. Seseorang disebut santri apabila belajar kepada Kiai secara personal maupun kelembagaan, baik santri tersebut masih menimba ilmu di pesantren maupun telah lulus atau keluar dari pesantren. ${ }^{6}$

\section{Tujuan Pondok Pesantren}

Pesantren merupakan lembaga pendidikan yang bertujuan untuk pendalaman ilmu agama (tafaqquhfi al-din) atau ilmu-ilmu yang berkaitan dengan keagamaan untuk membentuk anak didik yang ahli dalam bidang ilmu agama dan membentuk moralitas umat melalui pendidikan. ${ }^{7}$ Pesantren tetap eksis dalam mengkarakterisasi peserta didiknya sejak awal sampai sekarang dan akan terus dilakukan karena bagi pesantren, pendidikan adalah menanamkan budi pekerti luhur kepada jiwa-jiwa yang sedang berkembang sehingga menjadi watak dan karakter. Pendidikan harus dipahami sebagai suatu tindakan sadar untuk membentuk watak dan tingkah laku secara sistematis, terencana dan terarah, maka pendidikan adalah proses interaksi dari pendidik, terdidik dan lingkungan yang mengarah pada terbentuknya karakter baik peserta didik yang mampu memotori sikap dan perilaku yang sarat dengan nilai-nilai karakter yang baik. $^{8}$

${ }^{5}$ MA. Sahal Mahfudh, "Santri dan Pluraitas Masyarakat", Makalah disampaikan padaseminar "Santri Dalam Masyarakat Plural”, Lirboyo, Kediri, 7 Juni 2002, hal. 3

${ }^{6}$ Ali Usman, Kiai Mengaji Santri Acungkan Jari, hal. 6

${ }^{7}$ Bubun Suharto, Dari Pesantren Untuk Umat, Reinventing Eksistensi Pesantren di Era Globalisai, (Surabaya: Penerbit Imtiyaz, 2011), hal. 11

${ }^{8}$ MA. Sahal Mahfudh, "Profesionalisme Guru Pendidikan Agama Islam dan Pembentukan Kepribadian Siswa", Makalah disampaikan pada seminar sehari GPAI SD se Kabupaten Jepara, Jepara: 3 Juni 1993, hal. 2 
Dalam konteks pendidikan secara nasional, Pondok pesantren merupakan institusi pendidikan Islam asli Indonesia yang berbasis masyarakat hingga saat ini menjadi salah satu warisan kekayaan bangsa Indonesia yang terus berkembang. Output pendidikan di pesantren mengarah pada terciptanya manusia yang Sholeh dan Akram. ${ }^{9}$ Sholeh dan akram kemudian diharapkan menjadi landasan bagi setiap tindakan manusia dalam situasi berbangsa dan bernegara ini untuk membentuk insan yang mandiri dan merdeka. ${ }^{10}$ Karena konsep pendidikan pesantren mengadopsi hadits Nabi Muhammad SAW "Setiap anak yang dilahirkan dalam keadaan bersih (fitrah), kedua orang tuanyalah yang menjadikannya Yahudi, Nasrani atau Majusi", ${ }^{11}$ maka menciptakan insan sholeh dan akram menjadi target utama pendidikan pesantren. $^{12}$

Kemudian dengan berjalannya waktu lambat laun mengalami perkembangan dimana institusi ini juga menyiapkan anak didik memiliki pengetahuan umum dan bahkan diharapkan para santrinya memiliki skill tertentu, hal ini mendorong pesantren sacara bertahap mengubah struktur dan sistem pendidikannya. ${ }^{13}$ Jalaluddin bahkan mencatat bahwa paling tidak pesantren telah memberikan dua macama kontribusi bagi pendidikan di Indonesia. Pertama, adalah melestarikan dan melanjutkan sistem pendidikan rakyat, dan kedua, mengubah sistem pendidikan aristokratis menjadi sistem pendidikan demokratis. ${ }^{14}$

Pendapat pakar pendidikan pesantren, Kiai. Sahal yang menyatakan pesantren merupakan "sistem" adalah pandangan yang sangat proporsional. Kiai Sahal menandasakan: Pada dasarnya pesantren adalah sebuah sistem, yaitu sekelompok orang yang hidup bersama dalam sebuah komunitas dengan ikatan-ikatan aturan tertentu. Dengan demikian pesantren berarti mengandung unsur-unsur kelembagaan (institusi), kehidupan (pergaulan hidup) bersama dan aturan-aturan yang mengikat yang pada gilirannya terbentuk suatu lingkungan

${ }^{9}$ MA. Sahal Mahfudh, "Orientasi Kegiatan dan Peranan Pesantren”, Makalah disampaikan pada Temu wicara nasional guna meningkatkan peranan pesantren dalam proses pengembangan dan pembangunan masyarakat, Kaliurang Yogyakarta, 25 - 28 Februari 1988, hal. 2

Kiai Sahal menyampaikan hal senada (Sholeh dan Akrom) pada pidato peringatan satu abad berdirinya Madrasah Mathali'ul Falah, sebagai Direktur Perguruan Islam Mathali'ul Falah Kajen Margoyoso Pati Jateng 12 Desember 2012. Sholeh merujuk pada ayat 105 surat al-Anbiya yang diidealkan secara potensial mampu berperan aktif, terampil dan berguna dalam kehidupan sesama mahluk. Akram, merujuk pada ayat 13 al-Hujarat yang merupakan pencapaian kelebihan dalam relevansinya dengan makhlik terhadap khaliq. Lebih dari itu kata akram juga mencakup etika pergaulan dengan masyarakat dalam segala aspek kehidupan.

${ }^{10}$ Alfoe Ni'am Alwie, Naskah Buku Pesantren Maslakul Huda: Membentuk Insan Mandiri, hal. 7

${ }^{11}$ Lihat: Abdullah Muhamamd bin Ismail al-Bukhori, Shahih al Bukhori, (Beirut: Dar al Ma'rifah), Jilid I, hal. 456

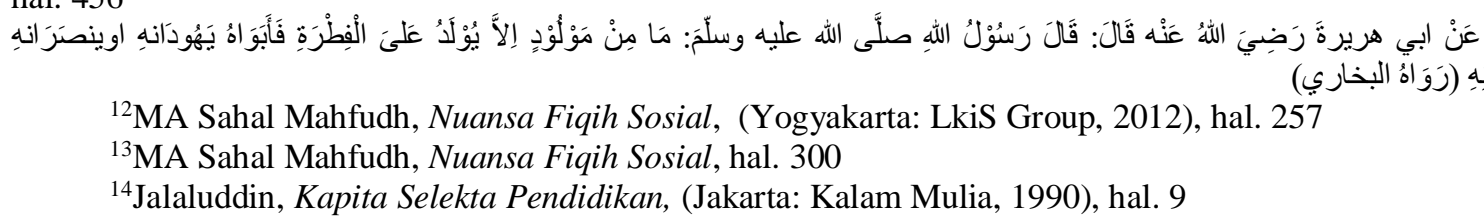

${ }^{14}$ Jalaluddin, Kapita Selekta Pendidikan, (Jakarta: Kalam Mulia, 1990), hal. 9 
hidup pesantren. Maka dalam pesantren setidak-tidaknya ada susunan atau struktur, ada pranata baik normatif maupun yang formal, ada tradisi adat, ada budaya, politik dan pergerakan atau dinamika. ${ }^{15}$

Kiai Sahal memandang dan menganggap semua aspek yang ada di pesantren secara menyeluruh sebagai satu kesatuan yang sama, baik aspek fisik berupa santri maupun non fisik berupa aspek kelembagaan, struktur, pranata, tradisi dan budaya, politik dan dinamika. Pandangannya ini pada akhirnya menjadi hal yang selalu menjadi pertimbangan dalam mencapai tujuan pesantren. Artinya aspek aspek yang ada itu menjadi dasar pendekatan dalam menentukan tujuan pesantren. ${ }^{16}$

Perlu dipikirkan secara lebih serius oleh kalangan pesantren adalah bagaimana mengembangkan wawasan dan keterampilan praktis untuk mengelola program kemasyarakatan. Harus diakui, referensi klasik yang digunakan pesantren selama ini tidak memberikan keterampilan praktis yang diperlukan kecuali dalam urusan ritual peribadatan. Mau tidak mau, harus ada upaya serius untuk menekuni ilmu-ilmu "baru" yang bersifat sosial. Ini agak sulit karena di alam bawah sadarnya pesantren masih menganggap ilmu-ilmu semacam itu tidak termasuk dalam kelompok ilmu yang wajib dituntut oleh setiap muslim dan muslimah. ${ }^{17}$

Sejak awal, keberadaan pesantren diakui sangat erat dengan kehidupan masyarakat sekelilingnya, bahkan pesantren menyatu dengan masyarakat sehingga pesantren merupakan bagian integral dari masyarakat. ${ }^{18}$ Sebagai sebuah sistem, pesantren hidup sebagai suatu kesatuan yang memiliki batas-batas yang menandainya dari masyarakat lain. Akan tetapi pesantren dalam lingkup sistem masyarakat secara umum, merupakan sub sistem masyarakat sehingga pesantren berada pada posisi mempengaruhi dan dipengaruhi. Dalam hal ini berarti pesantren merupakan sistem yang terbuka (open system) karena sebagai sebuah sistem, pesantren mempunyai hubungan relasi yang kuat dengan lingkungan dimana pesantren itu ada. Inilah karakter pesantren sejak awal berdirinya sampai saat ini, namum belakangan ini banyak

${ }^{15}$ MA. Sahal Mahfudh, "Pesantren Dalam Dinamika Perjuangan Bangsa", Makalah disampaikan pada Halaqah Pengasuh Pondok Pesantren tentang Kontribusi Pesantren Dalam Pengembangan Pendidikan Nasional, Semarang: 16 oktober 2003, hal. 1

${ }^{16}$ MA. Sahal Mahfudh, "Pesantren Dalam Dinamika Perjuangan Bangsa".

${ }^{17}$ MA. Sahal Mahfudh, "Meneguhkan Kembali Peran Sosial Pesantren: Petikan Pengalaman Pengembangan Masyarakat", Makalah disampaikan pada seminar Pemberdayaan Pesantren untuk Transformasi Masyarakat, Pusat Pengkajian Islam dan Masyarakat (PPIM) UIN Jakarta, 17 Mei 2005, hal. 14

${ }^{18}$ Pendapat "pesantren sebagai bagian integral dari masyarakat" dapat ditelusuri dari sejarah pesantren yang kebanyakan didirikan oleh masyarakat sendiri (santri yang datang untuk belajar atau oleh masyarakat disekitarnya), didukung dengan Kiai sebagai pimpinannya yang selalu berbaur dengan mayarakat dan menjadi inspirasi kehidupan masyarakat. 
pesantren tidak lagi menjadi bagian integral dari masyarakat sekitar. Sejatinya keberadaan Pesantren membuat masyarakat sekitar lebih berdaya, karena sejarah pesantren tidak lepas dari peran masyarakat. ${ }^{19}$

Sistem terbuka memiliki interaksi yang intensif dengan lingkungannya. Dan menjadi sebuah keniscayaan bahwa tiap-tiap sub sistem masyarakat selalu terlibat dalam persinggungan-persinggungan sistem sosialnya. Perubahan dalam lingkungan akan mempengaruhi sistem pesantren begitupula sebaliknya sistem pesantren akan mempengaruhi lingkungan disekitaranya. Giddens dalam bukunya teori strukturasi mengatakan bahwa pada dasanya seluruh masyarakat merupakan sistem sosial dan sekaligus persinggunganpersinggungan sistem sosial ganda. ${ }^{20}$ Pengembangan potensi masyarakat pesantren memang sudah dilakukan oleh pesantren dan hanya bersifat sporadis. Aktivitas pengembangan masyarakat belum dilakukan pesantren secara lembaga atau institusi dan belum juga disertai dengan visi yang jelas, serta prangkat pendukungnya. ${ }^{21}$

\section{Potret Pesantren Maslakul Huda}

Pesantren Maslakul Huda yang berjarak 18 kilometer ke arah utara dari kota Pati. Tepatnya desa Kajen, Kecamatan Margoyoso, Kabupaten Pati, Jawa Tengah. Pesantren ini lahir di tengah pergolakan perjuangan Bangsa Indonesia mengusir penjajah dari muka bumi Nusantara dengan membawa keinginan luhur pendirinya supaya memberikan sumbangsih kepada nusa, bangsa dan agama salam wujud pembekalan ilmu dan pembentukan watak serta kepribadian yang islami. Karenanya, kebodohan dan keterbelakangan membutuhkan insaninsan yang bertanggungjawab serta dapat mengangkat kembali harkat dan martabat bangsa. Pesantren Maslakul Huda yang didirikan pada tahun 1910 M. Dalam perjalannannya pesantren ini mengalami empat kali pergantian pengasuh, yakni setelah KH. Mahfudh wafat digantiakn oleh adiknya. KH. Ali Mukhtar, dan sesudah itu pimpinan pesantren dipegang oleh $\mathrm{KH}$. Muhammad Ahmad Sahal Mahfudh dan saat ini diasuh oleh KH. Abdul Ghaffar Rozien.

Pesantren Maslakul Huda (PMH) adalah institusi pendidikan yang berorientasi pada pengembangan tafaqquh fiddin dengan berbagai ciri intrinsiknya berusaha mempersiapkan insan yang soleh-akrom melalui pendekatan-pendekatan yang kognitif, afektif, dan

19 Husmiyati Hasyim, Trasformasi Pendidikan Islam: Konteks Pendidikan Pondok Pesantren, Jurnal Pendidikan Agama Islam-Ta'lim. Vol 13 No 1, 2015, hal. 76

${ }^{20}$ Anthony Giddens, Teori Struktursi untuk Analisis Sosial, terj. Ahmad Fahri, (Pasuruan: Pedati, 2004), hal. 202

${ }^{21}$ MA. Sahal Mahfudh, Pesantren Mencari Makna, (Jakarta: Pustaka Ciganjur dan KMF Jakarta, 1999), Cet. I, hal. 3 
psikomotorik. Pesantren Maslakul Huda mengalami perkembangan sistem dan kurikulum signifikan, dengan target menciptakan manusia mandiri yang sholeh dan akrom, dan menempatkan peserta didik sebagi subyek dan bukan obyek dalam setiap aktifitas kependidikannya. Setiap individu adalah manusia yang merdeka dan berhak menentukan setiap pilihannya, kemerdekaan dalam memilih dan menentukan hanya bisa dilakukan jika dalam sistem itu ada unsur yang namanya demokrasi. ${ }^{22}$

Sistem pendidikan pesantren dalam pengembangan Pesantren Maslakul Huda terdiri dari tiga elemen penting: Pertama, Pesantren menggunakan sistem pendidikan dengan mengedepankan tradisi-tradisi klasik yang unik, Kedua, Pesantren sebagai transformator nilai dan gagasan untuk masyarakat, Ketiga, Pesantren sebagai lembaga pengembangan masyarakat. Ketiga elemen tersebut bermuara pada terwujudnya kehidupan bahagia baik di dunia maupun di akhirat.

Pesantren Maslakul Huda adalah salah satu pesantren yang menggunakan sistem pendidikan dengan mengedepankan tradisi-tradisi klasik yang unik dan tidak ada sekat dengan masyarakat sekitar. Pesantren ini masuk dalam kategori pesantren tradisional dalam sistem pembelajaran klasik seperti memaknai kitab berbahasa jawa arab pegon dengan menggunakan simbol-simbol dalam pemaknaanya dan pengelolaannya sudah menggunakan sistem manajemen yang cukup terukur. ${ }^{23}$

\section{Manajemen Pesantren Maslakul Huda Kajen Pati Jateng Dalam Pembentukan Insan Mandiri}

Manajemen diartikan sebagai proses merencanakan, mengorganisasikan, memimpin, dan mengendalikan upaya organisasi dengan segala aspeknya agar tujuan organisasi tercapai secara efektif dan efisien. Agar kinerja pengurus pesantren lebih optimal dan mengetahui sejauh mana tingkat keberhasilan program kerja yang sudah dilakukan dan yang akan dilakukan, pelaporan tertulis hasil sidang evaluasi pengurus pondok pesantren dalam pelaksanaan kerjanya dilaksanakan setiap tiga bulan sekali dihadapan pengasuh utama, hal ini dimaksudkan agar kinerja pengurus pesantren lebih optimal. ${ }^{24}$

${ }^{22}$ Bambang Budiwiranto, "Pesantren and Participatory Development: The Case of the Pesantren Maslakul Huda of Kajen Pati Central Java”, dalam Journal of Indonesia Islam, Vol 03, No 02, Desember 2009, Pascasarjana-Lembaga Studi Agama dan Sosial IAIN Sunan Ampel, hal. 278

${ }^{23}$ Wawancara dengan HAL. Dliya Ulhaq, Pembantu pengasuh bidang Keorganisasian dan BUMP, Kajen Pati Jateng, 22 Maret 2019

${ }^{24}$ Wawancara dengan KHAL. Ahmad Mutamakkin, Pembantu Pengasuh bidang Pendidikan dan Ustadz/Guru Pondok Pesantren Maslakul Huda, Kajen Pati Jateng, 22 Maret 2019 
David Gordon mengatakan bahwa institusi manajemen modern harus menjalankan enam fungsi, yaitu: perencanaan, pengorganisasian, penyusunan staf, pengkoordinasian, pengarahan, dan pengendalian. ${ }^{25}$ Dengan fungsi manajemen ini, Nanang Fattah menambahkan bahwa manajemen dapat dikatakan meliputi perencanaan (planning), pengorganisasian (organizing), kepemimpinan (leading), dan pengawasan (controlling). ${ }^{26}$

\section{Sistem Rekrutmen}

Rekrutment pengeloaan pengurus pesantren Maslakul Huda berjalan demokratis dan sistematis dengan sistem struktur presidium terdiri dari 7 santri senior yang terdiri dari Presidium I, II, dan III yang masing-masing beranggotakan 2 orang serta satu ketua presidium yang menjabat sebagai koordinator. ${ }^{27}$ Presidium I menempati fungsi sebagai ketua pondok, Presidium II sebagai sekretaris, dan presidium III berperan sebagai keamanan. Jalur kordinasi yang dilaksanakan oleh Dewan Presidium adalah: Presdium I sebagai kordinator pendidikan memiliki sub seksi yaitu Sub Pengajian, Sub Musyawarah, Sub Muraja'ah dan Sub Tabligh. Presidium II sebagai kordinator Seksi TPBA (Tim Pengembangan Bahasa Arab), Seksi Kebersihan dan Seksi Perpustakaan. Presidium III sebagai kordinator Seksi Sosial dan Kesehatan dan Seksi Penerangan. ${ }^{28}$

Sistem rekrutmen pengurus khususnya anggota Presidium di Pesantren ini (Maslakul Huda) bukan dilihat dari lama seorang santri menempuh pendidikan pesantren ataupun dilihat dari umurnya. Namun dibatasi bahwa anggota presidium harus sudah menempuh tingkatan Aliyah. Dan juga anggota (presidium) diangkat tentunya memiliki berbagai trade record dan kredit poin sebagai aktifis di berbagai jenjang pengkaderan yang ada di Pesantren Maslakul Huda. Untuk melihat trade record santri dari keaktifan yaitu santri yang aktif dalam kepanitiaan PAVAL (Panitia Ihltifal), PAPSRA (Panitia Peringatan 10 Syuro) lalu dirapatkan dalam pleno siapa yang layak untuk mengurus pesantren pada kepengurusan berikutnya. ${ }^{29}$

\section{Sistem Perencanaan}

Konsep ini dijelaskan oleh KH. MA. Sahal Mahfudh yaitu sebagai upaya menjadikan santri yang kami didik menjadi sholeh sebagai khalifah fil ard yaitu santri yang mampu

${ }^{25}$ Davis Gordon B, Kerangka Dasar Sistem Informasi Menejemen, terj. Andreas S. Adiwardana (Jakarta: PT Pustaka Binama Pressindo, 2002), hal. 100

${ }^{26}$ Nanang Fattah, Landasan Manajemen Pendidikan, (Bandung: Remaja Rosdakarya, 2004), hal. 1.

${ }^{27}$ Umi Hanik, "Peran Pengelola Pondok Pesantren dalam Memajukan Sikap Kebebasan Berfikir Santri:Studi Kasus di Pondok Pesantren Maslakul Huda Kajen Pati”, dalam Jurnal Pendidikan, Jilid 14, Nomo 2 , Juli 2005, hal.185.

${ }^{28}$ Umi Hanik, "Peran Pengelola Pondok Pesantren dalam Memajukan Sikap Kebebasan Berfikir Santri:Studi Kasus di Pondok Pesantren Maslakul Huda Kajen Pati”, hal.186.

${ }^{29}$ Wawancara dengan HAL. Dliya Ulhaq, Pembantu pengasuh bidang Keorganisasian dan BUMP, Kajen Pati Jateng, 22 Maret 2019 
mengelola bumi serta mewarisinya dengan baik dan benar untuk memakmurkan dan mensejahterakan umat. Jika kesolehan ini sudah terbentuk, maka akan menghasilkan insan "akram yaitu santri yang hidup dalam keimanan dan ketaqwaaan kepada Allah SWT. ${ }^{30}$

Setiap awal tahun seluruh pengurus mengadakan sidang pleno perencanaan program kerja untuk satu tahun. Pengurus pesantren membahas teknis, dari iuran per santri, beli sapu, dan kebutuhan pesantren selama satu tahun. Semuanya diputuskan dan disepakati oleh seluruh pengurus pesanten dari berbagai seksi-seksi melalui siding pleno. Kewenangan penuh diberikan pengasuh kepada pengurus harus dimanfaatkan sebaik-baiknya. Pengasuh hanya mengesahkan hasil kesepakatan dan keputusan sidang yang dilaksanakan pengurus pesantren.

Kewenangan penuh yang diberikan diharapkan kelak para santri memiliki kemampuan pemimipin pesantren terasah dan menjadi bekal penting setelah lulus dari pesantren dan kembali ke lingkungan sosialnya, karena lingkungan sosial di pesantren adalah miniatur lingkungan sosial kemasyarakatan di dearahnya masing-masing.

\section{Sistem Pengorganisasian}

Biasanya di sebuah pesantren, struktur pengorganisasian berada langsung di bawah kontrol dan kendali pengasuh yang menggunakan sistem sentralistik dengan kepengurusan model ketua atau lurah pondok. Sistem ini mengasumsikan ketua atau lurah pondok berperan sebagai penanggungjawab operasional dari berlangsungnya kegiatan pesantren, sementara kebijakan penuh dan pengambilan keputusan masih ditangan Kiai sebagai pengasuh. Penelitian penulis menyimpulkan bahwa pesantren Maslakul Huda melaksanakan sistem yang berbeda. Sistem yang digunakan bukan ketua atau lurah pondok, meskipun fungsi dan tanggung jawabnya ada yang berperan dalam posisi tersebut. ${ }^{31}$

Di pesantren ini menggunakan sistem presidium, dalam hal ini Presidium ini diberikan kebebasan penuh yang bertanggung jawab di dalam mengelola keberlangsungan roda kepengurusan yang menggerakkan semua bentuk aktifitas. Bahkan dalam keadaan tertentu presidium akan dibiarkan ketika meminta pemecahan masalah kepada pengasuh. Hal ini dilakukan supaya presidium sebagai pengurus untuk selalu berikhtiar mencari jawaban dari masalah yang dihadapi, mereka mesti kreatif dan inovatif didalam menghadapi setiap masalah. Kepengurusan Pesantren Maslakul Huda yang dipegang oleh santri bukan hanya sebagai pelatihan organisasi, tetapi pelatihan bagaimana mengelola pesantren. Pengasuh memberikan

\footnotetext{
${ }^{30}$ Wawancara dengan KHAL. Abdul Ghaffar Rozin, Pengasuh Pondok Pesantren Maslakul Huda, Kajen Pati Jateng, 01 November 2014

${ }^{31}$ Mochal. Taufiq Ridho, Sistem Pengkaderan Berorganisasi Santri: Studi Kasus di Pesantren Maslakul Huda Kajen Margoyoso Pati Jawa Tengah, hal. 129
} 
mandat penuh kepada pengurus yang masih berstatus santri aktif untuk mengelola pesantren. Setiap pengurus di pondok ini adalah Kiai di pesantren ini, setiap Kiai manapun tidak ada yang menginginkan pesantrennya tidak berkembang. Pengasuh memberikan kebebasan dan keluasan kepada kami untuk mengatur dan mengurus pesantrennya. ${ }^{32}$

Hal senada disampaikan oleh KH. Ahmad Mutamakkin, Pembantu pengasuh bidang pendidikan bahwa semua pembantu pengasuh hanya sebagai kosultan, tidak bisa memberikan keputusan. Keputusan tetap dan mengikat ada di pengurus pesantren. Itu lah pembelajaran kemandirian yang berbeda dengan pesantren lain. ${ }^{33}$ Jadi, perannya pengasuh dan pembantu pengasuh pesantren hanya sebagai konsultan, dan mengajar pengajian kitab kepada seluruh santri pada waktu yang sudah ditentukan pengurus.

Pesantren ini memiliki ciri khas pada implementasi manajemen pengkaderan beroganisasi santri yang tidak ditemukan di beberapa pesantren lain dan mempunyai dampak yang baik dalam membekali kemampuan dan pengalaman kepada santri tentang organisasi untuk bekal kemadirian mereka berinteraksi dengan lingkungan sosialnya.

Penulis menilai bahwa keorganisasian pesantren dengan system presidium menganut sistem kolektif kolegial yang diidealkan oleh pesantren dalam mendidik santri berorganisasi dan bermasyarakat. Dengan sistem ini kewenangan bisa dikatakan sepenuhnya berada di tangan santri, pengasuh hanya berperan sebagai motivator dan supervisor. Pengasuh berperan dalam situasi tertentu yang memang memungkinkan atau mengharuskan melakukan langkahlangkah tersebut. Hal tersebut dilakukan untuk menempa nilai-nilai kesadaran, kemandirian, persamaan, semangat kerja sama, solidaritas dan keikhlasan.

Dalam sistem pengorganisasian, santri yang notabenenya sebagai pengurus dilibatkan langsung dalam pengelolaan administrasi dan manajemen pesantren. Kepengurusan pesantren tersebut menggunakan sistem presidium yang memimpin bidang-bidang tertentu. Sistem kepresidiuman ini memiliki corak yang lain dengan pesantren pada umumnya. Dengan sistem ini, organisasi akan dapat bergerak dan hidup apabila masing-masing bagaian memiliki program kerja untuk masa satu tahun sebab tiap periode kepengurusan hanya berlaku satu tahun kemudian dipilih kembali.

Pergerakan di Pesantren Maslakul Huda adalah membuat semua pengelola pesantren mengoptimalkan sumber daya insani (SDI) baik sebagai pengasuh, pengurus beserta para seksi

\footnotetext{
${ }^{32}$ Wawancara dengan HAL. Dliya Ulhaq, Pembantu pengasuh bidang Keorganisasian dan BUMP, Kajen Pati Jateng, 22 Maret 2019

${ }^{33}$ Wawancara dengan KHAL. Ahmad Mutamakkin, Pembantu Pengasuh bidang Pendidikan dan Ustadz/Guru Pondok Pesantren Maslakul Huda, Kajen Pati Jateng, 22 Maret 2019
} 
dan sub seksi, serta para santrinya untuk bekerjasama yang dilandasi keikhlasan dalam suatu manajemen pesantren. Sistem pergerakan ini dilaksanakan sesuai dengan struktur organisasi secara vartikal namun tidak bersifat komando dan juga sistem kordinasi. Dengan sistem ini santri merasa di hargai, karena mereka juga dilatih untuk berfikir kritis. ${ }^{34}$

Pengkaderan dan pendidikan di Pesantren Maslakul Huda memang dijalankan dengan sistematis. Santri tertentu yang menjabat presidium danjajaran dibawahnya dalam kepengurusan setiap periodenya benar-benar dibekali berbagai kemampuan dan pengalaman melalui sistem ini. Namun disamping evaluasi hasil dari program pesantren, bagi pesantren ini keberhasilan suatu pesantren tidak dapat diukur berdasarkan prestasi-prestasi individual para santrinya, tetapi pada sejauh mana santri mampu berinteraksi secara positif dengan masyarakatnya. ${ }^{35}$

Hal ini yang menjadi target utama pencapaian pesantren Maslakul Huda dalam mencetak insan mandiri. Konsep dasar pesantren dalam menciptakan insan madiri bahwa tujuan dasar pesantren kami mengacu pada terciptanya Insan shaleh akram. Konsep ini dijelaskan oleh KH. MA. Sahal Mahfudh yaitu sebagai upaya menjadikan santri yang dididik menjadi sholeh sebagai khalifah fil ard yaitu santri yang mampu mengelola bumi serta mewarisinya dengan baik dan benar untuk memakmurkan dan mensejahterakan umat. Jika kesolehan ini sudah terbentuk, maka akan menghasilkan insan "akram yaitu santri yang hidup dalam keimanan dan ketaqwaaan kepada Allah SWT. ${ }^{36}$

Di pesantren ini hasil belajar berupa praktek melalui perilaku dan sikap santri dijadikan sebagai acuan keberhasilan pendidikan pesantren dan dari proses pendidikan pesantren, inilah diharapkan akan tumbuh manusia-manusia mandiri yang kuat secara intelektual, ideal dalam kepribadian dan memiliki ketrampilan yang siap pakai. ${ }^{37}$ Bahkan dalam mendidik para santri untuk mandiri pengasuh pesantren mengajarkan kemandirian dalam mengurus pesantren secara teknis, dari iuran, beli sapu, dan kebutuhan pesantren. Semuanya diputuskan dan disepakati oleh seluruh pengurus pesanten dal berbagai seksi-seksi. ${ }^{38}$

\footnotetext{
${ }^{34}$ Umi Hanik, "Peran Pengelola Pondok Pesantren dalam Memajukan Sikap Kebebasan Berfikir Santri:Studi Kasus di Pondok Pesantren Maslakul Huda Kajen Pati”, hal.185.

${ }^{35}$ MA. Sahal Mahfudh, "Santri dan Pluralitas Masyarakat", Malalah disampaikan pada seminar santri dalam masyarakat plural, Lirboyo, 7 Juni 2002, h 2

${ }^{36}$ Wawancara dengan KHAL. Ahmad Mutamakkin, Pembantu Pengasuh bidang Pendidikan dan Ustadz/Guru Pondok Pesantren Maslakul Huda, Kajen Pati Jateng, 22 Maret 2019

${ }^{37}$ Wawancara dengan KHAL. Ahmad Mutamakkin, Pembantu Pengasuh bidang Pendidikan dan Ustadz/Guru Pondok Pesantren Maslakul Huda, Kajen Pati Jateng, 22 Maret 2019

${ }^{38}$ Wawancara dengan HAL. Dliya Ulhaq, Pembantu pengasuh bidang Keorganisasian dan BUMP, Kajen Pati Jateng, 22 Maret 2019
} 
Karenanya, di pesantren ini, besarnya kewenangan yang diberikan pengasuh kepada pengurus harus mampu dimanfaatkan sebaik-baiknya. Dengan demikian, kemampuan pemimipin pesantren bagi santri akan terasah dan menjadi bekal penting setelah lulus dari pesantren dan kembali ke lingkungan sosialnya, karena lingkungan sosial di pesantren adalah miniatur lingkungan sosial kemasyarakatan di dearahnya masing-masing.

\section{Sistem Pengawasan.}

Sistem pengawasan di pesantren Maslakul Huda yaitu dengan memberikan kemerdekaan berfikir dan mendorong kritisisme dengan mengikutsertakan santri-santri (pengurus) dalam setiap kebijakan yang akan diambil dan dilaksanakan bersama. Pengasuh sangat mempercayakan penuh kepada pengurus pesantren yang notabenenya sebagai santri aktif. Perlu diketahui, pada umumnya, pola menejemen pendidikan pesantren cenderung dilakukan secara insidental dan kurang memperhatikan tujuan-tujuannya yang telah di sistematisasikan secara hierarkis. Sistem pendididikan pesantren biasanya dilakukan secara alami dengan pola menejerial yang tetap sama dalam setiap tahunnya. ${ }^{39}$ Akan tetapi pesantren Maslakul Huda telah melakukan perubahan dalam mengawasi keberlangsungan menejemen pendidikan pesantren dengan lebih demokratis.

Demokrasi dan profesionalisme selama ini mendasari setiap langkah dan kebijakan yang diambil oleh pihak pesantren. Makna demokrasi sesungguhnya tidak terletak hanya pada aspek kelembagaan resmi, tetapi pada nilai, semangat, dan subtansi demokrasi yang menghormati dan menjunjung tinggi prinsip-prinsip pluralitas, kemanusiaan, kejujuran, objektifitas, rasionalitas, transparansi, tanggungjawab, keadilan dan kemerdekaan individu. ${ }^{40}$

Keikutsertaan semua pihak dalam proses pengambilan sebuah keputusan disadari betul oleh pengasuh bahwa sebuah lembaga pendidikan berbentuk pesantren "Maslakul Huda" yang meletakkan azas dari santri oleh santri dan untuk santri melalui pengkaderan model presidium. Sistem pengawasan di pesantren Maslakul Huda bersifat demokratis. Yang dilakukan adalah mendorong terwujudnya proses pendidikan yang kritis-emansipatoris dalam rangka membentuk Insan mandiri yang sholih dan akrom. Karenanya dibutuhkan partisipasi dan keikutsertaan semua pihak dalam prosesi pelaksanan kepengurusan termasuk santri sebagai peserta didik, pengasuh, pembantu pengasuh dan masyarakat sebagai mitra-sosial. ${ }^{41}$

${ }^{39}$ Armai Arief, Reformulasi Pendidikan Islam, (Jakarta: CDRS PRESS), Cet I, hal. 49

${ }^{40}$ MA. Sahal Mahfudh, "Demokratisasi dan Pendidikan Demokrasi", Makalah disampaikan pada diskusi interaktif dengan tema "Pengembangan Kuliah Kerja Nyata di Era Otonomi Daerah" di Balai Penelitian dan Pengembangan Masyarakat INISNU Jepara, 10 Maret 2001, hal. 1-2 t.d

${ }^{41}$ Wawancara dengan KHAL. Ahmad Mutamakkin, Pembantu Pengasuh bidang Pendidikan dan Ustadz/Guru Pondok Pesantren Maslakul Huda, Kajen Pati Jateng, 22 Maret 2019 
Inti pengawasan yang demokratis adalah keterbukaan dan keinginan memposisikan pekerjaan dari oleh, dan untuk bersama. Tipe demokratis bertolak dari asumsi bahwa hanya dengan kekuatan kelompok, tujuan-tujuan bermutu dapat dicapai. Menurut Sudarwan Danim dalam bukunya "Motivasi Kepemipinan dan Efektivitas Kelompok" bahwa tipe demokratis berusaha lebih banyak melibatkan anggota kelompok dalam memacu sebuah tujuan dan tugas serta tanggung jawab dibagi-bagi menurut bidang masing-masing. ${ }^{42}$

Apa yang dikatakan Sudarwan Danim dilaksanakan di pesantren Maslakul Huda. H. Dliya Ulhaq menjelaskan pengasuh dan pembantu pengasuh hanya memantau dan mengawasi kebijakan apa yang diambil oleh pengurus pesantren yang dilakukan dengan cara diskusi dan musyawarah mufakat dan mereka sangat menjunjung tinggi kebijakan di pesantren yang disepakati. $^{43}$

Dengan sistem pengawasan seperti itu, tentunya menjadikan peserta didik belajar kemandirian dan menghormati segala keputusan yang sudah disepakati bersama. Pendidikan karakter yang dilakukan yaitu membentuk insan yang mandiri dan merdeka. Merdeka dalam arti berhak merefleksikan segenap keinginan dan pemikirannya dalam koridor tanggung jawab dan insan mandiri yang independen dan mampu bersaing dengan pihak lain dalam berbagai kancah pergulatan kehidupan sosial. ${ }^{44}$ Kiai Sahal telah merumuskan dan menanamkan sistem pengawasan yang demokratis terhadap kepengurusan pesantren. Subtansi demokrasi yatiu menghormati dan menjunjung tinggi prinsip-prinsip yang disepakati, kejujuran, objektifitas, rasionalitas, transparansi, tanggungjawab, keadilan dan kemerdekaan individu.

Usaha Pengasuh dalam mendemokratisasi sistem pendidikan di Maslakul Huda merupakan konteks komunikasi baik sebagai hasil dari terciptanya insan merdeka dan mandiri yang soleh dan akrom. Sikap demokratis ini sesuai dalam surat Asy Syura "Dan (bagi) orangorang yang menerima (mematuhi) seruan Tuhannya dan mendirikan shalat, sedang urusan mereka (diputuskan) dengan musyawarat antara mereka; dan mereka menafkahkan sebagian dari rezki yang Kami berikan kepada mereka." (QS Asy Syura [19]: 38) ${ }^{45}$ Kontek ayat ini mengajarkan umat manusia untuk bersikap lemah lembut melalui jalur musyawarah untuk mufakat, tidak boleh dengan hati yang kasar, perilaku kekerasan dan otoriter. Pesantren

${ }^{42}$ Sudarwan Danim, Motivasi Kepemimpinan dan Efektivitas Kelompok, (Jakarta: PT. Rinika Cipta, 2004), Cet. 1, hal. 75 .

${ }^{43}$ Wawancara dengan HAL. Dliya Ulhaq, Pembantu pengasuh bidang Keorganisasian dan BUMP, Kajen Pati Jateng, 22 Maret 2019

${ }^{44}$ Alfoe Ni'am Alwie, Naskah Buku Pesantren Maslakul Huda: Membentuk Insan Mandiri, (Yogyakarta: Wisma KMF Papringan, 21 April 2004), hal. 99

${ }^{45}$ QS Asy Syura [19]: 38

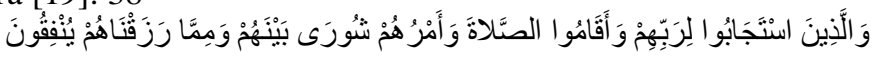


Maslakul Huda dalam konsep mendidik santri-santrinya sangat demokratis sebagai bentuk pengawasan karena mengutamakan musyawarah untuk mufakat tidak otoriter dalam menyelesaikan setiap urusan dan apabila telah dicapai suatu kesepakatan, maka semua pihak harus menerima termasuk pengasuh pesantren.

\section{Materi Pendidikan}

Hampir sama dengan pesantren-pesantren lain, penerapan kurikulum pesantren Maslakul Huda bersifat mandiri dan otonom. Memang rata-rata pesantren seperti itu (otonom dalam penetapan kurikulum tanpa mengikuti kurikulum yang ditetapkan pemerintah). ${ }^{46}$ Mengenai kurrikulum pesantren Said Agil Siradj menjelaskan: Penyeragaman kurikulum atau materi pendidikan pesantren tidak mutlak dan tidak mungkin dipaksakan kepada semua pesantren. ini bukan saja karena latar belakang dan aspirasi masing-masing pesantren tetapi hambatan yang paling sulit dicari jalan keluarnya adalah subjektifitas dan tingkat kemampuan pengasuh dan masih cukup kuat pengaruh dinastinya. ${ }^{47}$ Oleh karena itu materi yang diajarkan antara satu pesantren dengan pesantren lain biasanya berbeda. Perbedaan itu terletak pada pemilihan spesifikasi kitabnya ataupun metode penyampaiannya. Namun semua perbedaan itu tetap bermuara pada fungsi pesantren yaitu sebagai lembaga tafaqquh fi al-diin.

Secara kurikulum dan aktifitas Maslakul Huda dan Madrasah Mathali’ul Falah adalah sebuah sistem yang disatupadukan dalam sistem pendidikan pesantren yang ditawarkan. Padahal Pesantren Maslakul Huda dan Madrasah Mathali'ul Falah adalah institusi berbeda yang saling mendukung. Aktifitas keduanya saling menunjang dan melengkapi bahkan secara kurikulum dan waktu pelaksanannya saling mensiasati dan menyesuaikan. Kegiatan kependidikan yang berlangsung di pesantren Maslakul Huda, selain dengan disesuaikan waktu sholat rawatib, juga disesuaikan dengan berbagai kegiatan kependidikan santri di Mathali'ul Falah. Karena sebagian besar santri Maslakul Huda adalah murid Madarasah Mathali'ul Falah kegiatan kependidikan yang berlangsung di pesantren Maslakul Huda, selain dengan disesuaikan waktu sholat rawatib, juga disesuaikan dengan berbagai kegiatan kependidikan santri di Mathali'ul Falah. Aktifitas santri dimulai dengan sholat subuh berjama'ah dilanjutkan belajar bersama dan mengkaji kitab kuning dengan materi ajaran tajwid dan baca Al-Qur'an. setelah itu sekitar pukul 06.00 membersihkan halaman pesantren bagi yang piket dan yang lain antri mandi karena mereka harus menyesuaikan jadwal masuk Madrasah dengan menghitung waktu dan fasilitas yang ada. Disini santri secara langsung akan terlatih untuk membudayakan

\footnotetext{
${ }^{46}$ Wawancara dengan KHAL. Ahmad Mutamakkin, Pembantu Pengasuh bidang Pendidikan dan Ustadz/Guru Pondok Pesantren Maslakul Huda, Kajen Pati Jateng, 22 Maret 2019

${ }^{47}$ Lanny Octavia, Pendidikan Karakter Berbasis Tradisi Pesantren, (Jakarta: Rumah Kitab, 2014), hal. xii.
} 
disiplin dan antri dalam melakukan setiap aktifitas yang mereka lakukan. Setelah itu mereka harus mengikuti kegiatan belajar di Madrasah mulai pukul 07.30 sampai 12.30 dan sholat dhuhur mereka wajib berjama'ah di Masjid Jami' Kajen, setelah itu mereka pulang dan makan siang. 48

Perkembangan yang terjadi di pesantren dengan berbagai aktifitas dan kesibukannya secara personal, banyak diantara santri sudah tidak lagi melakukan liwetan (masak sendiri), kalaupun ada jumlahnya sangat sedikit, sebagian besar mereka kost makan, dan mereka diberi kebebasan untuk memilih tempat kost. Pesantren meyediakan bagi yang berminat, selain itu ada juga yang kost makan di warung makan dan rumah masyarakat sekitar. Hal ini merupakan salah satu bentuk kebijakan pesantren sebagai usaha membangun relasi dengan masyarakat, selain sebagai wahana komunikasi dalam rangka proses integrasi, hal ini juga bisa menjadi lahan peningkatan pemasukan ekonomi masyarakat sekitar dengan menjual jasa kepada para santri. Namun kadangkala disisi yang lain hal ini akan menimbulkan persoalan baru antara pesantren dan masyarakat ketika terjadi suatu kasus antara santri yang kost makan dengan induk semangnya atau masyarakat penyedia jasa, namun hal ini sebenarnya malah bisa menjadi wahana pelatihan santri dalam proses belajar bermasyarakat dan memecahkan masalah dengan pihak lain.

Dalam proses pembelajarannya, pesantren Maslakul Huda hampir sama dengan pesantren pada umumnya yaitu mempergunakan suatu bentuk materi tertentu yang telah lama dipergunakan, yaitu sistem penghataman kitab kuning dalam bidang studi tertentu sesuai dengan jenjang atau tingkatannya. ${ }^{49}$ Sehingga akhir sistem pembelajaran di pondok pesantren Maslakul Huda berstandar pada tamatnya buku atau kitab yang dipelajari.

Berbeda dengan pesantren lain di Nusantara, Pesantren Maslakul Huda menerapkan sistem kurikulum yang elastis yang esensinya mengikuti kurikulum dirosah Madrasah Mathali'ul Falah, tetapi materi pengajian dan kitab-kitab yang dikaji ditentukan oleh pengurus sebagai representasi dari seluruh santri melalui sidang pleno. Hal ini sebagai tujuan menjadikan insan mandiri. ${ }^{50}$ Penerapan sistem dalam materi pembelajaran di Pesantren Maslakul Huda sangat bermanfaat bagi kemandirian santri dalam mengetahui kebutuhannya. Konsep musyawarah mufakat pengurus pesantren (santri aktif) dalam penentuan kurrikulum pesantren sebagai penopang dari kurrikulum Madrasah Mathali'ul Falah tanpa campur tangan pengasuh

\footnotetext{
${ }^{48}$ Alfoe Ni'am Alwie, Naskah Buku Pesantren Maslakul Huda: Membentuk Insan Mandiri, hal. 87

${ }^{49}$ Mahmud Yunus, Sejarah Pendidikan Islam di Indonesia, (Jakarta: Hidakarya Agung, 1985), hal. 69

${ }^{50}$ Wawancara dengan KHAL. Ahmad Mutamakkin, Pembantu Pengasuh bidang Pendidikan dan Ustadz/Guru Pondok Pesantren Maslakul Huda, Kajen Pati Jateng, 22 Maret 2019
} 
pesantren merupakan salah satu cara bagaimana pesantren ini mencetak santri-santri menjadi insan mandiri. Para santri juga dididik agar menjadi seorang yang terampil, informal leader, berorientasi keahlian, inventif dan kreatif. Jadi secara umum Program-program pesantren Maslakul Huda adalah sebagai berikut :

a. Program pendidikan intelektual, meliputi:

1) Pengajaran dasar-dasar Islam (Aqidah/tauhid, ilmu-ilmu alat/adab), ilimu-ilmu syari'at (Fiqh, Ushul fiqh, Qoidah fiqhiah, Tafsir Al- Quran) dan nilai-nilai keulamaan.

2) Pengajaran aktualisasi kitab kuning/pengajian dengan dialog, diskusi, ceramah ilmiah, bedah kitab/buku, training tabligh, tahfidz al- kutub (Alfiah, Nadzom almaqsud, Amstilah al-tashrifiyah,'Imrithi, Tauhid, Jauhar al-maknun, Mantiq, Lathaiful Isyarah, Faraid) dan sebagainya.

b. Program pendidikan kemasyarakatan, diwujudkan dengan kerja sama penanganan lingkungan dengan masyarakat.

\section{Metode Pendidikan}

Pencapaian pendidikan pesantren Maslakul Huda yaitu mencetak muslim ideal yang sholih dan akrom untuk menjadi insan mandiri, tentunya di butuhkan seperangkat aturan dan bahan ajaran serta metode pendidikan yang efektif agar tujuan pendidikan pesantren dapat tercapai sesuai dengan yang diharapkan. Selain itu kegiatan santri juga dikontrol melalui ketetapan dalam tata tertib dan materi pelajaran yang sudah disepakati saat sidang pleno pengurus pesantren, semua ini dilakukan untuk mendukung terwujudnya proses pendidikan yang dapat membentuk karakter mulia para santri.

Metode yang di implementasikan pada desain pembelajaran menempati posisi yang krusial dalam sebuah pendidikan, karena dengan metode tersebut akan menentukan mudah tidaknya materi dapat diterima oleh peserta didik. ${ }^{51}$ Sedangkan metode pembelajaran pesantren yang paling mendukung terbentuknya pendidikan karakter para santri adalah proses pembelajaran yang integral melalui metode belajar-mengajar (dirosah wa ta'lim), pembiasaan prilaku luhur(ta'dib), aktivitas spiritual (riyadhah) serta teladan yang baik (uswah hasanah) yang dipraktekkan dan dicontohkan langsung oleh kiai, nyai dan para ustadz. ${ }^{52}$

Tidak jauh berbeda dari penjelasan metode pendidikan pesantren bahwa materi pelajaran yang bersifat implementasi dan tidak ada panduan tertulisnya adalah semua santri di pesantren

\footnotetext{
${ }^{51}$ Bermawi Munthe, Desain Pembelajaran, (Yogyakarta: Pustaka Insan Madani), Cet. 10, hal. 1

${ }^{52}$ Babun Suharto, Dari Pesantren Untuk Umat: Reinveting Eksistensi Pesantren di Era Globalisasi, (Surabaya: Imtiyaz, 2011), Cet. 1, hal. 20
} 
ini, dalam kesehariannya dituntut untuk hidup mandiri dalam berbagai hal. Mulai dari persoalan sederhana seperti mengatur keuangan yang dikirim orang tua agar cukup untuk sebulan, mencuci pakaian, sampai pada persoalan serius seperti belajar dan memahami pelajaran. Pola didik seperti itu sangat penting dalam mewujudkan tujuan pesantren ini, membentuk insan mandiri sholeh dan akrom tentunya. ${ }^{53}$ Sedangkan cara mengajar yang sifatnya mengarah pada materi pelajaran tertulis sama dengan pesantren lain, seperti bandongan, wetonan, ma'nani kitab kuning dan lain-lain ${ }^{54}$

Namun pengurus pesantren secara total mengatur semua pekerjaan rumah sendiri. Seperti menentukan kitab apa yang akan dikaji tahun ini lalu diajukan kepada usatidz pesantren. ${ }^{55}$ Pengajian di Pesantren Maslakul Huda berjalan baik, karena seksi pendidikan sebagai penanggungjawab cukup aktif program pengajian ini. Dan mengontrol santri yang bolos pengajian. Karena hal itu sudah menjadi program mereka.

Metode pengajaran di pesantren Maslakul Huda hampir sama dengan pesantren lain di Nusantara yaitu menerapkan juga metode bandongan, ${ }^{56}$ sorogan, ${ }^{57}$ munadzorh, ${ }^{58}$ dan musyawarah. ${ }^{59}$ Hal tersebut sangat bermanfaat dalam rangka membangkitkan semangat intelektual santri untuk tampil menguji mentalitas dalam berdiskusi dan bicara di depan halayak. Dalam metode ini santri diajak berfikir kritis terhadap suatu permasalahan tertentu dengan menggunakan penalaran-penalaran ilmiah yang berlandaskan pada Al-Qur'an dan Hadits serta kitab-kitab klasik sebagai media mencetak manusia shaleh dan akram menuju

\footnotetext{
${ }^{53}$ Wawancara dengan KHAL. Ahmad Mutamakkin, Pembantu Pengasuh bidang Pendidikan dan Ustadz/Guru Pondok Pesantren Maslakul Huda, Kajen Pati Jateng, 22 Maret 2019

${ }^{54}$ Wawancara dengan KHAL. Ahmad Mutamakkin, Pembantu Pengasuh bidang Pendidikan dan Ustadz/Guru Pondok Pesantren Maslakul Huda, Kajen Pati Jateng, 22 Maret 2019

${ }^{55}$ Wawancara dengan KHAL. Ahmad Mutamakkin, Pembantu Pengasuh bidang Pendidikan dan Ustadz/Guru Pondok Pesantren Maslakul Huda, Kajen Pati Jateng, 22 Maret 2019

${ }^{56}$ Bandongan atau biasa disebut metode wetonan adalah cara penyampaian kitab kuning di mana seorang guru, kiai atau ustadz membacakan dan menjelaskan isi kitab kuning. Sementara santri, murid atau siswa mendengarkan, memberi makna dan menerima wejangan.

${ }^{57}$ Sorogan adalah metode belajar yang berbeda dengan metode bandongan. Dalam metode sorogan, murid membaca kitab kuning dan memberi makna, sementara guru mendengarkan sambil memberi catatan, komentar atau bimbingan bila diperlukan.

${ }^{58}$ Munadhoroh atau diskusi, yaitu suatu pertemuan ilmiah yang secara spesifik membahas masalah-masalah diniyah ibadah (ritual). Dalam pelaksanaanya tidak hanya sebatas membahas masalah agama (masailul diniyyah) tetapi juga membahas masalah-masalah yang kontekstual yang terjadi di masyarakat. Dalam munadhoroh tersebut dapat dibedakan atas dua tingkat kegiatan. Pertama, munadhoroh diselenggarakan oleh sesama santri untuk membahas suatu masalah dengan tujuan melatih para santri agar terlatih dalam memecahkan persoalan dengan mempergunakan kitab kitab yang tersedia. Kedua, munadhoroh yang dipimpin oleh kiai atau mendatangkan narasumber dari luar pesantren.

${ }^{59}$ Musyawaroh, atau biasa disebut Bahtsul Masa'il hampir sama dengan metode munadhoroh namun metode musyawaroh ini lebih membahas maasalah-masalah fiqhiyah, aqidah (teologi) serta masalah-masalah kontemporer yang timbul di masyarakat.
} 
insan mandiri. ${ }^{60}$ Pesantren ini dalam menjalankan metode yang diterapkan berpijak pada suatu maqolah yang cukup terkenal " Al muhafadhotu 'ala al qodim al sholih wal akhdzu bi al jaded al ashlah yang artinya memelihara dalam arti yang luas dan aktif hal-hal yang telah ada sejak lama yang dipandang baik, patut dan tepat, dan mengambil dan menggunakan inovasi baru yang dipandang lebih baik dan lebih maslahah. ${ }^{61}$

Dari metode tersebut diharapkan santri benar-benar dituntut untuk mandiri, mandiri tidak hanya dalam mengurus kebutuhan keseharian mereka, tetapi juga mandiri dalam kegiatan pendidikannya. Kemandirian ini akan semakin lengkap apabila dalam pengelolaan kegiatan pendidikan pesantren, pengurus (santri senior) diberi kewenangan lebih untuk merencanakan dan merumuskan program-program, bukan bermaksud mengurangi kewenangan pengasuh, tetapi hal tersebut merupakan langkah kaderisasi dan pelatihan bagi santri dalam mengelola sebuah lembaga. Apa yang dilakukan pesantren Maslakul Huda tampaknya yang masih belum banyak dilakukan oleh pesantren pada umumnya. Kebanyakan dari mereka terjebak dalam pemahaman tadzim. Padahal seyogyanya tadzim memang sangat dianjurkan tetapi kalau berlebihan dan tidak sewajarnya sehingga tadzim itu lebih terasa sebagai budaya feodal yang amat kuat.

\section{Kesimpulan}

Semakin kuat mempertahankan tradisi, semakin berkarakter dalam berinovasi. Pesantren Maslakul Huda masih menggunakan sistem pembelajaran dengan mengedepankan tradisi-tradisi klasik, seperti sorogan, bandongan, munadzorah, bahtsul masail dan memaknai kitab bahasa jawa dengan tulisan arab pegon menggunakan simbol-simbol dalam pemaknaanya. Secara pengelolaan, pesantren Maslakul Huda sudah menggunakan manajemen yang baik dan terukur dimulai dari: sistem rekrutmen pengurus pesantren yang notabenenya santri aktif, sistem pengorganisasian, pengawasan, materi dan metode pendidikan yang bermuara pada terbentuknya insan mandiri.

\footnotetext{
${ }^{60}$ MA. Sahal Mahfudh, "Orientasi Kegiatan dan Peranan Pesantren," makalah disampaikan pada Temu Wicara Nasional Guna Meningkatkan Peranan Pesantren dalam Proses Pembangunan dan Pengembangan Masyarakat, Jogjakarta, 25 - 28 Februari 1982, hal. 3 t.d

${ }^{61}$ MA. Sahal Mahfudh, "Orientasi Kegiatan dan Peranan Pesantren," 


\section{Daftar Pustaka}

Arief, Armai, Reformulasi Pendidikan Islam, (Jakarta: CDRS PRESS), Cet I.

Budiwiranto, Bambang, "Pesantren and Participatory Development: The Case of the Pesantren Maslakul Huda of Kajen Pati Central Java", dalam Journal of Indonesia Islam, Vol 03, No 02, Desember 2009, Pascasarjana-Lembaga Studi Agama dan Sosial IAIN Sunan Ampel

Bahrudin dan Esa Nur Wahyuni, Teori Belajar dan Pembelajaran, (Jogjakarta: Ar-Ruzz Media Group, 2007), Cet. 1.

Danim, Sudarwan, Motivasi Kepemimpinan dan Efektivitas Kelompok, (Jakarta: PT. Rinika Cipta, 2004), Cet. 1.

Dhofier, Zamakhsyari, Tradisi Pesantren: Studi Tentang Pandangan Hidup Kiai, (Jakarta: LP3ES, 1982)

Fattah, Nanang, Landasan Manajemen Pendidikan, (Bandung: Remaja Rosdakarya, 2004)

Giddens, Anthony Teori Struktursi untuk Analisis Sosial, terj. Ahmad Fahri, (Pasuruan: Pedati, 2004).

Gordon B, Davis, Kerangka Dasar Sistem Informasi Menejemen, terj. Andreas S. Adiwardana (Jakarta: PT Pustaka Binama Pressindo, 2002)

Hanik, Umi, "Peran Pengelola Pondok Pesantren dalam Memajukan Sikap Kebebasan Berfikir Santri:Studi Kasus di Pondok Pesantren Maslakul Huda Kajen Pati”, dalam Jurnal Pendidikan, Jilid 14, Nomo 2, Juli 2005.

Hasyim, Husmiyati, Trasformasi Pendidikan Islam: Konteks Pendidikan Pondok Pesantren, Jurnal Pendidikan Agama Islam-Ta'lim. Vol 13 No 1, 2015.

Indah Purnamasari, Nia, Konstruksi Sistem Pendidikan Pesantren Tradisional di Era Global: Paradoks dan Relevansi. Sekolah Tinggi Agama Islam YPBWI Surabaya, EL-BANAT: Jurnal Pemikiran dan Pendidikan Islam Volume 6, Nomor 2, Juli-Desember 2016

Jalaluddin, Kapita Selekta Pendidikan, (Jakarta: Kalam Mulia, 1990)

Mahmud, Yunus, Sejarah Pendidikan Islam di Indonesia, (Jakarta: Hidakarya Agung Mastuki HS, Intelektualisme Pesantren: Seri 3, (Jakarta: Diva Pustaka, 2003)

Mahfudh, MA. Sahal, "Profesionalisme Guru Pendidikan Agama Islam dan Pembentukan Kepribadian Siswa", Makalah disampaikan pada seminar sehari GPAI SD se Kabupaten Jepara, Jepara: 3 Juni 1993

, "Santri dan Pluralitas Masyarakat", Malalah disampaikan pada seminar santri dalam masyarakat plural, Lirboyo, 7 Juni 2002.

, "Demokratisasi dan Pendidikan Demokrasi", Makalah disampaikan pada diskusi interaktif dengan tema "Pengembangan Kuliah Kerja Nyata di Era Otonomi Daerah" di Balai Penelitian dan Pengembangan Masyarakat INISNU Jepara, 10 Maret 2001.

"Orientasi Kegiatan dan Peranan Pesantren", Makalah disampaikan pada Temu wicara nasional guna meningkatkan peranan pesantren dalam proses pengembangan dan pembangunan masyarakat, Kaliurang Yogyakarta, 25 - 28 Februari 1988

, Nuansa Fiqih Sosial, (Yogyakarta: LkiS Group, 2012)

, "Pesantren Dalam Dinamika Perjuangan Bangsa", Makalah disampaikan pada Halaqah Pengasuh Pondok Pesantren tentang Kontribusi Pesantren Dalam Pengembangan Pendidikan Nasional, Semarang: 16 oktober 2003.

"Meneguhkan Kembali Peran Sosial Pesantren: Petikan Pengalaman Pengembangan Masyarakat", Makalah disampaikan pada seminar Pemberdayaan Pesantren untuk Transformasi Masyarakat, Pusat Pengkajian Islam dan Masyarakat (PPIM) UIN Jakarta, 17 Mei 2005. 
Pesantren Mencari Makna, (Jakarta: Pustaka Ciganjur dan KMF Jakarta, 1999), Cet. I.

Munthe, Bermawi, Desain Pembelajaran, (Yogyakarta: Pustaka Insan Madani), Cet. 10.

Ni'am Alwie, Alfoe, Naskah Buku Pesantren Maslakul Huda: Membentuk Insan Mandiri, (Yogyakarta: Wisma KMF Papringan, 21 April 2004)

Octavia, Lanny, Pendidikan Karakter Berbasis Tradisi Pesantren, (Jakarta: Rumah Kitab, 2014), 1985)

Tim Penulis, Pengembangan Pendidikan Kesetaraan di Pondok Pesantren, (Jakarta: Direktorat Jendral Pendidikan Islam, 2008

Usman, Ali, Kiai Mengaji Santri Acungkan Jari, (Yogyakarta: Pustaka Pesantren, , 2013), Cet. I.

Suharto, Bubun, Dari Pesantren Untuk Umat, Reinventing Eksistensi Pesantren di Era Globalisai, (Surabaya: Penerbit Imtiyaz, 2011)

Wawancara dengan H. Dliya Ulhaq, Pembantu pengasuh bidang Keorganisasian dan BUMP, Kajen Pati Jateng, 22 Maret 2019

Wawancara dengan KH. Ahmad Mutamakkin, Pembantu Pengasuh bidang Pendidikan dan Ustadz/Guru Pondok Pesantren Maslakul Huda, Kajen Pati Jateng, 22 Maret 2019 